\title{
LINGKUNGAN BAHASA ARAB DI PEMONDOKAN SANTRI MAHASISWA PONDOK PESANTREN MAMBAUS SHOLIHIN
}

\author{
Mohammad Makinuddin \\ Institut Keislaman Abdullah Faqih Gresik, Indonesia \\ E-mail: kinudd@gmail.com
}

\begin{abstract}
There have been a number of factors shaping and determining the success of learning and mastering foreign langua-ges, including Arabic language. Along with learning activities to achieve excellent ability in comprehending Arabic language, language environment becomes another most essential factor. The existence of Arabic environment ( $\hat{\imath}$ 'ah lughawîah 'Arabîyah) beco-mes an exceptionally pivotal because it brings about what so-called "contextual learning activity" around the students. The article discusses the case of Mambaus Sholihin Islamic Boarding School which develops such language environment. The study shows that this Islamic educational institution has faced, however, several problems regarding inconsistent implementation of the language environment even though there have been numerous language instructors graduated from a number of universities in the Middle East and Indonesia as well as Islamic boarding schools in Indonesia. Specifically, these are a number of problems as regards to the issue: 1) there has been no such an organizing team; 2) the students have no self-confidence to practice Arabic; 3) the human resources engaging in the implementation of the Arabic environment have less motivation to earnestly run it; 4) bad influence of senior students to the new students; and 5) there has been no strong awareness to use Arabic for daily communication.
\end{abstract}

Keywords: Bîah lughawîyah 'Arabîyah; contextual learning activity.

\section{Pendahuluan}

Pondok Pesantren merupakan salah satu lembaga pendidikan yang menjadi kawah candradimuka dalam pengembangan bahasa Asing, terlebih pengembangan dan pembelajaran bahasa Arab. Ada banyak studi yang menjadi bukti tentang keberhasilan pesantren dalam kertas kerja ini. 
Sistem pendidikan pesantren yang menerapkan long life time education (pendidikan sepanjang waktu) memberikan ruang terjadinya praktik bahasa Asing yang intens dan kontinu, mulai dari bangun hingga menjelang tidur. Sistem dan aktivitas inilah yang membentuk lingkungan bahasa di pesantren.

Lingkungan bahasa (bî'ah lughawîyah) menjadi vital sebagai salah satu faktor yang mempengaruhi dan menentukan keberhasilan pembelajaran dan penguasaan bahasa Asing, tak terkecuali bahasa Arab. Keberadaan bî'ah lughawîyah 'Arabîyah (lingkungan bahasa Arab) tidak bisa dipisahkan dari satu kesatuan sistem pembelajaran bahasa karena sifatnya yang selalu hadir, melingkupi serta memberi nuansa relevan dan faktual dalam pembelajaran bahasa Arab itu sendiri.

Lingkungan mempunyai peranan penting dalam pembelajaran dan pemerolehan bahasa. Lingkungan disini didefenisikan sebagai semua unsur dan faktor baik materi maupun non-materi yang berpengaruh dalam proses pembelajaran dan menjadi stimulan bagi siswa untuk lebih semangat dalam meningkatkan ketrampilan bahasa, mendorong, dan memberanikan mereka untuk mempraktikkan dalam realitas kehidupan sehari-hari, atau segala sesuatu yang didengar dan dilihat oleh siswa dari sesuatu yang mempengaruhi mereka dalam mempelajari bahasa Arab. ${ }^{1}$

Pembelajaran dan pemerolehan bahasa memiliki banyak teori pembangun, baik bahasa pertama maupun bahasa kedua. Teori yang paling umum dan mendasar adalah teori behaviorisme dan teori nativisme. Konsep dasar teori behaviorisme dilandasi anggapan bahwa seseorang setelah lahir tidak memiliki apa-apa, sehingga dalam pemerolehan bahasa lingkungan sangat berperan penting. Dengan kata lain, lingkungan yang banyak memberi sumbangan kepada seseorang sehingga dapat memperoleh bahasa. Lain halnya dengan teori nativisme, bahwa seseorang sejak lahir sudah memiliki suatu alat pemerolehan bahasa yang disebut Language Acquistition Device (LAD). Melalui alat ini seseorang dapat memperoleh bahasa. Namun demikian, alat pemerole-

1 Halimi Zuhdi, "Lingkungan Bahasa Arab dan Perannya dalam Belajar Dan Pembelajaran di Pondok Pesantren al-Amien Prenduan Sumenep Madura" (Tesis--UIN Maulana Malik Ibrahim, 2007), ii. 
han bahasa tersebut dapat berfungsi apabila ada lingkungan yang mendukungnya. ${ }^{2}$

Pada saat yang sama, lingkungan bahasa yang sudah terbentuk perlu adanya pengelolaan yang maksimal. Tanpa pengelolaan yang maksimal, lingkungan yang sudah terbentuk akan tidak berjalan dengan baik dan konsisten, bahkan lingkungan tersebut dapat berubah menjadi lingkungan yang tak terkontrol dan gagal menjadi sub sistem penunjang keberhasilan dari sistem pembelajaran yang integral dan masif dalam kasus tertentu.

Salah satu pondok pesantren yang telah melakukan pengembangan bahasa Arab melalui pembentukan lingkungan bahasa adalah Pondok Pesantren Mambaus Sholihin (PPMS) Suci Manyar Gresik. Pesantren ini diasuh oleh KH. Masbuhin Faqih dan didirikan sejak tahun 1976. Pada tahun 2015, PPMS telah memiliki lima cabang yang tersebar di Jawa dan luar Jawa. Keberhasilan pengembangan fisik ini dalam hemat penulis tidak lepas dari keberhasilan pesantren dalam menciptakan sistem pembelajaran integratif antara model salaf (tradisional) dan khalaf (modern). Bahasa telah menjadi ikon dari produk pendidikan pesantren ini sehingga dapat eksis dan bertahan dalam arus modernitas yang semakin kompetitif dalam bidang pendidikan. Fenomena ini dalam pandangan penulis layak untuk menjadi subjek studi berbasis partisipatoris, yang hasilnya bisa memberikan kontribusi bagi pengembangan bahasa Arab di pesantren dan menjadi prototipe sistem pembelajaran bahasa Asing, khususnya bahasa Arab di Indonesia.

\section{Lingkungan Bahasa}

\section{Pengertian Lingkungan Bahasa}

Lingkungan bahasa merupakan segala sesuatu dan semua faktor yang bersifat material dan immaterial yang bertujuan untuk mempengaruhi proses pembelajaran bagi peserta didik dalam pengembangan bahasa Arab, serta memotivasi mereka untuk mengaplikasikan bahasa dalam keseharian. ${ }^{3}$ Lingkungan bahasa juga identik dengan istilah lingkungan belajar, karena baik lingkungan bahasa dan lingkungan belajar punya keterkaitan satu sama lain sebagai proses belajar dan pembelajaran bahasa

2 Tamam Hasan, al-Tambîd fî Iktisâb al-Lughah al-'Arabîyah li Ghayr Nâtiqîn bihâ (Makkah: Wizârat al-Ta'lîm al-'Âlî Jâmi'at Umm al-Qurâ, 1984), 7.

3 Marzuqi, Dawrat al-Lughânîyah fî̀ Tarqîyat al-Lughah al-'Arâbîyah (Makalah disampaikan dalam Seminar di UIN Mualana Malik Ibrahim Malang, 2001). 
Arab. Satu sisi lingkungan bahasa dapat membentuk dan memberikan stimulan terhadap proses belajar, begitu juga sebaliknya. Maka untuk memahami lingkungan bahasa, dapat dilakukan dengan sebuah pendekatan awal melalui proses mengetahui pengertian dari istilah lingkungan belajar secara umum. ${ }^{4}$

Șalâh 'Abd al-Majîd al-'Arabî menuturkan bahwa lingkungan belajar sebagai semua unsur yang meliputi pengajar; mulai dari kitab ajar, metode pembelajaran, kegiatan pembelajaran di dalam kelas dan di luar kelas, di tengah-tengah pembelajaran, sesudah dan sebelumnya. ${ }^{5}$ Dari penjelasan ini didapatkan pengertian bahwa lingkungan bahasa bisa dimaknai sebagai segala unsur yang meliputi pengajar bahasa baik sebelum, saat proses, dan sesudah pembelajaran yang dilakukan. ${ }^{6}$

Namun sebagian orang mengartikan lingkungan secara sempit, seolah-olah lingkungan hanya alam sekitar di luar diri manusia. Padahal pengertian lingkungan mencakup segala materi dan stimulus di dalam dan di luar diri individu, baik yang bersifat fisiologis, psikologis, maupun sosial-kultural. Dengan demikian lingkungan dapat diartikan dan dipahami secara fisiologis, psikologis, dan sosio-kultural.

Secara fisiologis, lingkungan meliputi segala kondisi dan material jasmaniah di dalam tubuh. Secara psikologis, lingkungan mencakup

4 Sehubungan dengan pemanfaatan lingkungan sebagai sumber belajar ini, bahwa pemanfaatan lingkungan sebagai sumber belajar dapat dilakukan dengan dua cara yaitu: dengan cara membawa sumber-sumber dari masyarakat dan lingkungan ke dalam kelas dan dengan cara membawa siswa ke lingkungan. Tentunya masing-masing cara tersebut dapat dilakukan dengan pendekatan, metoda, teknik dan bahan tertentu yang sesuai dengan tujuan pengajaran. Lihat Novrianti, Pemanfaatan Lingkungan sebagai Sumber Belajar, dalam http:/ / sweetyhome.wordpress.com, diakses 15 Januari 2015

5 Ṣâhh Abd al-Majîd al-Arabî, Ta'allum al-Lughah al-Hayyah wa Ta'lîmuhâ (Kairo: Maktabah Lubnân, 1981), 11.

6 Lebih sempit lagi pengertian yang dikutip oleh Martinis dari pendapat Hutabarat bahwa lingkungan belajar ialah segala sesuatu yang terdapat di tempat belajar. Sedang Nasution mendefinisikan lingkungan belajar yaitu lingkungan alami dan lingkungan sosial. Lingkungan alami seperti keadaan suhu, kelembaban udara, sedangkan lingkungan sosial dapat berwujud manusia dan representasinya maupun berwujud halhal lain. Prestasi belajar itu salah satunya dipengaruhi oleh lingkungan belajar. Menurut Dunn, kondisi belajar dapat mempengaruhi konsentrasi, pencerapan, dan penerimaan informasi. Senada dengan hal di atas Rachman menyatakan, lingkungan fisik tempat belajar mempunyai pengaruh penting terhadap hasil pembelajaran. Lihat Martinis, Lingkungan Belajar Berkulitas, dalam http://martinis1960.wordpress.com/2011/02/04 /lingkungan-belajar-berkualitas/ diakses pada 15 Januari 2015. 
segenap stimulan yang diterima oleh individu mulai sejak dalam kandungan, kelahiran (kehidupan) sampai kematiannya. Sedangkan secara sosio-kultural, lingkungan mencakup segenap stimulasi, interaksi dan kondisi dalam hubungannya dengan perlakuan ataupun karya orang lain. ${ }^{7}$ Dalam pandangan lain, lingkungan dapat meliputi semua kondisi dalam dunia ini yang dengan cara-cara tertentu mempengaruhi tingkah laku, pertumbuhan, perkembangan atau life processes manusia kecuali gen-gen. ${ }^{8}$

Mencermati pengertian lingkungan dari teori-teori di atas, penulis sampai pada satu simpulan umum untuk memahami terma dalam kertas kerja ini bahwa lingkungan bahasa identik dengan lingkungan belajar yang didalamnya terdapat proses yang simultan melibatkan subjek pembelajar dan sumber belajar bahasa yang mengarah pada terbentuknya pemahaman dan produktivitas pengunaan bahasa dalam ruang dan waktu tertentu.

\section{Karakter dan Peran Lingkungan Bahasa}

Lingkungan bahasa sangat berperan dalam menciptakan suasana belajar yang menyenangkan bagi pembelajar bahasa. Lingkungan tersebut dapat meningkatkan keaktifan pembelajar dan efektivitas belajar yang mengarah pada terwujudnya keberhasilan dari cita-cita pembelajaran itu sendiri. Secara umum ada dua macam lingkungan bahasa, yakni lingkungan bahasa natural (tabî'yyah) dan lingkungan bahasa artifisial (iștinâ'yyah). Dalam konteks tema tulisan ini, lingkungan bahasa yang dimaksud adalah lingkungan artifisial, dan menurut Krashen karakteristik lingkungan bahasa artifisial adalah: a). Lingkungan tersebut lingkungan buatan yang disengaja, b). Pengajar mengarahkan pembelajar untuk mempraktikkan kegiatan-kegiatan bahasa dengan menggunakan bahasa tujuan, dan c). Lingkungan yang berada di dalam sekolah.

Ada tiga kategori peranan yang diberikan lingkungan belajar bahasa dalam belajar bahasa sebagai berikut:

a. Peranan input (masukan). Istilah input diartikan sebagai 'sesuatu' yang diperoleh sebagai hasil interaksi. input berarti 'tenaga yang dimasukkan'; 'pemakaian'. input di lingkungan kelas berarti input yang pemerolehannya hanya melalui kegiatan di dalam kelas. Secara aksiomatis, pemerolehan bahasa kedua dapat berlangsung atau terjadi

\footnotetext{
${ }^{7}$ M. Dalyono, Psikologi Pendidikan (Jakarta: Rineka Cipta, 2012), 129-130.

8 M. Ngalim Purwanto, Ilmu Pendidikan: Teoretis dan Praktis (Bandung: Remaja Rosdakarya, 2011), 72.
} 
dengan lancar bila data bahasa kedua sebagai input dan seperangkat mekanisme internal tersedia. ${ }^{9}$

b. Peranan lingkungan formal. Lingkungan bahasa secara garis besar dapat diklasifikasikan ke dalam lingkungan formal dan lingkungan nonformal. Lingkungan formal adalah salah satu lingkungan belajar bahasa yang fokus pada penguasaan kaidah atau aturan-aturan bahasa secara sadar dalam bahasa target. Lingkungan ini dapat terjadi di dalam kelas, maupun di luar kelas. lingkungan formal masih mempunyai peranan dalam belajar bahasa.

c. Peranan lingkungan informal. Lingkungan informal terjadi secara alami. Yang tergolong lingkungan informal adalah bahasa yang dipakai kawan-kawan sebaya, bahasa pengasuh atau orang tua, bahasa yang dipakai anggota kelompok etnis pembelajar, bahasa yang dipakai di media cetak atau elektronika (koran, buku, televisi, atau radio), dan bahasa yang dipakai guru dalam proses belajar-mengajar di kelas bahasa maupun bukan bahasa. ${ }^{10}$

\section{Strategi Pembentukan Lingkungan Bahasa}

Dalam pembentukan berbagai diperlukan strategi agar apa yang diinginkan dapat berjalan dengan baik dan terstruktur. Dari berbagai kajian yang dilakukan oleh para pengkaji, penulis menemukan berbagai strategi dalam pembentukan lingkungan kebahasaan yang dapat dilakukan, antara lain:

a. Pembelajaran selalu menggunakan bahasa tujuan.

b. Tidak menunjukkan kesalahan seorang pembelajar di hadapan temantemannya.

c. Dalam pembelajaran diupayakan sedikit menjelaskan dan memperbanyak latihan dan penerapan bahasa tujuan.

d. Menjadikan pembelajar sebagai mitra dalam penerapan berbahasa.

e. Tulisan-tulisan bahasa tujuan baik di papan tulis, buku atau yang lainnya jelas dan mudah dibaca.

f. Mendorong pembelajar untuk menerapkan bahasa tujuan.

g. Diadakan kompetisi terkait bahasa antarpembelajar.

h. Memberikan waktu yang seluas-luasnya kepada pembelajar untuk berlatih dan menerapkan bahasa tujuan di luar sekolah.

9 Nurhadi dan Roekhan, Dimensi-Dimensi dalam Belajar Bahasa Kedua (Bandung: Sinar Baru Bandung, 1990), 111.

10 Ibid., 118. 
i. Membuat aturan-aturan yang disepakati oleh pembelajar dan pengajar dalam penggunaan dan penerapan bahasa tujuan. ${ }^{11}$

j. Strategi tersebut banyak dilakukan oleh pesantren-pesantren pengembang bahasa Arab dan pesantren yang menginginkan terbentuknya lingkungan bahasa. Strategi tersebut terus dijaga dan dijalankan secara berkesinambungan agar bahasa tujuan terbentuk dan diaplikasikan di lingkungan tersebut dengan aktif dan efektif serta semakin berkembang ke arah yang bertambah baik.

Sedangkan Ahmad Fuad Efendi menjelaskan, berbagai strategi yang bertujuan dan menjadi modal dalam menciptakan lingkungan bahasa antara lain:

a. Sumber daya manusia. Pengadaan sumber daya manusia yang memiliki kompetensi komunikatif bahasa baik lisan maupun tulis menjadi model sekaligus penggerak kegiatan kebahasaan, minimal mampu menjadi lawan bicara dalam berkomunikasi.

b. Lingkungan psikologis. Penciptaan lingkungan psikologis yang kondusif bagi pengembangan pembelajaran bahasa bisa dimulai dengan pembentukan citra positif di mata warga.

c. Lingkungan bicara. Penciptaan lingkungan bicara yaitu lingkungan yang menggunakan bahasa tujuan dalam interaksi sehari-hari, secara bertahap dan berkelanjutan memberi dampak yang kuat pada pemerolehan bahasa tujuan.

d. Lingkungan pandang atau baca. Penciptaan lingkungan ini relatif lebih mudah, apabila dirancang dengan baik sehingga memberi dampak yang cukup kuat bagi pemerolehan bahasa tujuan.

e. Lingkungan dengar. Penciptaan lingkungan ini bisa dilakukan dengan penyampaian pengumuman-pengumuman lisan dalam bahasa tujuan atau dengan cara lain.

f. Lingkungan pandang-dengar. Lingkungan ini bisa diciptakan dengan memanfaatkan teknologi informasi, misalnya pemutaran film yang menggunkan bahasa tujuan atau menampilkan tayangan yang menggunakan bahasa tujuan.

g. Kelompok pecinta bahasa tujuan. Pembentukan kelompok pecinta bahasa bertujuan untuk mewujudkan berbagai aktivitas yang bernuansa bahasa tujuan. ${ }^{12}$

11 Halimi Zuhdi, al-Bîah al-Lughawîyah Takwinuhâ wa Damruhâ fî̀ Iktisâb al-Arabîyah (Malang: UIN Malang Press, 2009), 56-58. 


\section{Profil Pondok Pesantren Mambaus Sholihin}

\section{Letak Geografis}

Mambaus Sholihin adalah sebuah institusi yang terletak di kawasan pegunungan Suci, bersuhu udara cukup hangat, $\pm 25^{\circ} \mathrm{C}$. Kawasan ini berada kurang lebih $3 \mathrm{Km}$ dari terminal Bunder (jalur utama SurabayaJakarta). Dua kilometer dari Pertigaan Desa Tenger Sukomulyo yang terletak di jalur pantura ini termasuk kawasan yang cukup makmur ekonominya. Dengan sumber daya alamnya serta pasokan air yang melimpah ruah-konon merupakan sumber mata air yang muncul pada saat Kanjeng Sunan Giri hendak berwudu saat itu—merupakan aset yang sangat berharga bagi masyarakat sekitar dan juga bagi Pesantren di sekitar wilayah tersebut.

Mambaus Sholihin berdiri di area perkebunan cukup luas, yang letak pemodokan antara santri putra dan putri dipisahkan oleh ruas jalan utama Bunder-Tenger, pemodokan putra berada di sebelah Barat jalan, dan pemodokan putri berada di sebelah timur jalan, sedangkan di sebelah selatan dari pondok induk yang berjarak sekitar 800 meter, pada tahun 2012 diresmikan gedung asram baru khusus santri putri pada tingkat awal. Pemisahan ini menjadi potonsi yang kondusif dalam melaksanakan proses pembelajaran, dan memudahkan proses pengasuhan antara santri putra dan putri.

Mengingat letaknya yang strategis-tepat di sebelah jalan utamadan mudah dijangkau dari berbagai penjuru dari berbagai desa di sekitar Gresik dan kota-kota sekitar, menjadikan Mambaus Sholihin sebagai sebuah institusi yang tergolong cepat berkembang di Kabupaten Gresik. ${ }^{13}$ Letak yang stategis inilah yang menjadi salah satu faktor penunjang dalam proses pengembangan kelembagaan, baik diukur dari kuantitas maupun kualitas.

\section{Sejarah Pendirian}

Pondok Pesantren Mambaus Sholihin dirintis oleh ayahanda Kiai Masbuhin Faqih, yaitu KH. Abdullah Faqih Suci sekitar tahun 1969 yang pada mulanya berupa surau kecil yang difungsikan untuk mengaji al-

12 Ahmad Fuad Effendi, Metodologi Pengajaran Bahasa Arab (Malang: Misykat, 2005), 168171.

13 Artikel dalam majalah, Yayasan Pondok Pesantren Mambaus Sholihin, al-Sirah Majalab Tabunan (Gresik: Yayasan Pondok Pesantren Mambaus Sholihin, 2004), 5. 
Qur'ân dan kitab kuning bagi masyarakat di lingkungan desa Suci dan sekitarnya.

Pada tahun 1976 Kiai Masbuhin yang baru mendapatkan restu dari gurunya, KH. Abdullah Faqih Langitan untuk berjuang di tengah masyarakat, namun beliau masih mempertimbangkan kembali untuk mendirikan sebuah pesantren. Meskipun pada saat itu semangat beliau untuk mendirikan pesantren sangat besar. Namun semangat itu ditundah oleh sebab perasaan khawatir jika niat beliau itu justru timbul dari nafsu (bubb al-talamidh), karena mendirikan pondok bagi beliau harus benarbenar didasari oleh keihlasan untuk nashr al-ilm (menyebarkan ilmu), bukan atas dorongan keinginan mendapatkan santri yang banyak.

Di kemudian hari, berkat dorongan dari guru-guru beliau yaitu: $\mathrm{KH}$. Abdul Hadi Zahid Langitan, KH. Abdullah Faqih Langitan, KH. Abdul Hamid Pasuruan, KH. Usman Al-Ishaqi Surabaya, serta keinginan luhur beliau untuk nashr al-ílm, maka didirikanlah sebuah pesantren yang kelak bernama Mambaus Sholihin. Adapun dana pertama kali yang digunakan untuk membangun pondok adalah pemberian guru beliau, Kiai Faqih Langitan. Pada saat pendirian pesantren, Kiai Masbuhin masih menimba serta mendalami ilmu di Pondok Pesantren Langitan.

Sebelum pesantren Mambaus Sholihin didirikan, Kiai Faqih Langitan sempat mengunjungi lokasi yang akan digunakan untuk membangun pesantren. Setelah beliau mengelilingi tanah tersebut, beliau berkata kepada Kiai Masbuhin, Yo wis tanah iki pancen cocok kanggo pondok, mulo ndang cepet bangunen. (Tanah ini memang cocok untuk dibangun pondok pesantren, maka dari itu cepat bangunlah). Tidak lama kemudian beberapa mashâyikh (sebutan jamak untuk kiai pengasuh pesantren) dan habâib (sebutan jamak untuk orang Arab keturunan nabi Muhammad) juga berkunjung ke lokasi tersebut,. Di antara mashâyikh dan ḥabâib yang hadir yaitu Kiai Abdul Hamid Pasuruan, Kiai Usman al-Ishaqi Surabaya, KH. Dimyati Rois Kaliwungu, Habib al-Idrus, dan Habib Macan dari Pasuruan.

Pada tahun $1402 \mathrm{H}$ atau tepatnya pada tahun $1983 \mathrm{M}$, dilakukan pembangunan musala Pondok Pesantren Mambaus Sholihin. Saat itu Kiai Masbuhin sedang menunaikan lbadah haji yang pertama. Adapun yang menjadi modal awal kegiatan pembangunan ini berasal dari uang yang dititipkan oleh seseorang yang tidak dikenal kepada adik kandung Kiai 
Masbuhin, yaitu KH. Asfihani yang waktu itu masih menjadi santri di Pondok Pesantren Salafiyah dalam asuhan Kiai Hamid di Pasuruan.

Konon ceritanya, saat itu Kiai Asfihani turun dari tangga sehabis mengajar, tiba-tiba ada seseorang yang tidak dikenal memberikan sekantong uang, kemudian orang itu pergi dan menghilang. Pada pagi harinya Kiai Asfihani dipanggil oleh Kiai Hamid, beliau berkata, Asfihani, saya ini pernah berjanji untuk menyumbang pembangunan rumah santri (ma'had) tapi hari ini saya tidak punya uang. Yai silihono dhuwit po'o nak!! (pinjami kiai uang ya!)". Kemudian Kiai Asfihani menjawab, tadi malam sebabis mengajar saya diberi orang sekantong uang. Sedangkan saya tidak kenal orang tersebut. Kiai Hamid berkata, endi saiki dhuwite ndang ayo diitung (di mana uangnya sekarang, ayo dihitung). Lalu Kiai Asfihani mengambil uang tersebut dan dihitung sebanyak Rp. 750.000,-. Pada akhirnya, Kiai Hamid memberi isyarat, bahwa yang memberikan uang tersebut adalah Nabi Khidir. Kemudian Kiai Hamid berkata pada Kiai Asfihani, Nak, saiki muliyo. Dhuwit iki ke'no abahmu kongkon bangun Musholla (Nak, sekarang pulanglah dan berikan uang ini kepada ayahmu untuk membangun musala). ${ }^{14}$

Suatu kisah yang juga menarik adalah suatu peristiwa yang terjadi ketika pondok induk dalam tahap penyelesaian pembangunan. Kiai Hamid waktu itu datang dan memberi sebuah lampu Neon 40 Watt 220 Volt untuk penerangan Pondok Pesantren Mambaus Sholihin. Padahal saat itu listrik belum masuk ke desa Suci. Mengingat pemberinya diyakini sebagai wali Allah, maka pengasuh pesantren yakin bahwasannya ini merupakan sebuah isyarat akan suatu hal yang belum diketahui. Ternyata tidak berselang lama, tepatnya pada tahun 1976, sampailah aliran listrik ke desa Suci. Rupanya lampu neon itu merupakan isyarat dari peristiwa tersebut, juga bisa berarti sebagai simbol gambaran kondisi pondok pesantren di masa mendatang, yang diharapkan mampu mencerahkan

14 Ibid. 5. Terhitung sejak mulai berdiri pada tahun 1980 Mambaus Sholihin telah menjelma menjadi pesantren terbesar di kabupaten Gresik dengan santri yang berjumlah ribuan. Kurikulum yang diimplementasikan adalah perpaduan sistem pesantren tradisonal dan modern. Selain sistem pendidikan, perkembangan Mambaus Sholihin juga ditunjang oleh aspek demografi dan sejarah. Sudah maklum dan menjadi kepercayaan di kalangan pesantren bahwa tempat yang pernah disinggahi dan didoakan oleh wali-wali Allah, maka keberkahan akan nampak di tempat itu. Itulah yang selama ini diyakini oleh kiai, guru dan santri di pesantren ini. Dengan semakain banyaknya ulama-ulama singgah di Mambaus Sholihin maka semakin besar berkah yang menjadi athar (dampak) karenanya. Untuk membaca kisah lengkap lihat Kilas Sejarah Mambaus Sholihin (Gresik: al-Fikrah edisi 88 Januari 2016 M/Rabiul Tsani 1437 H), 14. 
dan menerangi umat islam dan santri-santrinya seperti halnya lampu neon itu.

Pada pembangunan tahap selanjutnya, KH. Agus Ali Masyhuri Sidoarjo yang telah membeli sepetak tanah dari seorang warga Suci yang terletak di samping Masjid Jami' Suci 'Roudhotus Salam”, mewakafkan tanah tersebut untuk kepentingan pesantren sebagai lahan yang bisa dikembangkan sebagai pemondokan dan lembaga penunjang pembelajaran bagi santri. Tanah tersebutlah yang menjadi cikal-bakal pengembangan pondok putra sebagaimana didapati sekarang ini yang sangat luas, besar bahkan bisa dikata cukup megah.

\section{Sistem Pendidikan}

Pesantren Mambaus Sholihin tergolong pada pondok pesantren yang menerapkan model manajemen konvergensi yaitu perpaduan antara sistem pendidikan pondok pesantren tradisional (salafíyah) dan modern (khalaf) karena secara kultural masih menerapkan sistem salaf dan secara struktur telah menerapkan sistem manajerial yang mengadopsi dari teoriteori manajemen, terbukti dengan diterapkannya sistem pendidikan formal dan non-formal mulai dari pendidikan dasar sampai perguruan tinggi. Ini tidak lepas dari latar belakang pendidikan pengasuh pesantren, Kiai Masbuhin yang merupakan alumni Pondok Modern Gontor dan Pondok Pesantren Langitan. Kurikulum yang dikembangkan di Pondok Pesantren Mambaus Sholihin merupakan perpaduan antara tiga Pondok Pesantren yang menjadi kiblat aktivitas keseharian di Mambaus Sholihin: a. Pondok Modern Gontor. Mambaus Sholihin mengadopsi dari pesantren ini, kurikulum bahasa, baik bahasa Arab maupun bahasa Inggris sebagai bahasa sehari-hari santri, selain itu kurikulum organisasi juga diadopsi dari Gontor.

b. Pondok Pesantren Langitan. Mambaus Sholihin mengadopsi dari pesantren ini, kurikulum salaf terkait dengan referensi kitab kuning dan akhlak (moral keseharian) santri.

c. Pesantren Roudhotul Muta'allimin Surabaya. Mambaus Sholihin mengadopsi dari pesantren ini kurikulum 'ubûdîyah (tata cara beribadah), dan awrâd (amalan-amalan keseharian) santri. ${ }^{15}$

\section{Satuan Pendidikan Formal dan Non-Formal}

Mambaus Sholihin memiliki satuan pendidikan formal dan nonformal, yaitu: a. Taman Kanak-kanak Raudhotul Athfal Mambaus

15 Ibid., 6. 
Sholihin, b. Madrasah Ibtidaiyah Mambaus Sholihin, c. Madrasah Tsanawiyah Mambaus Sholihin, d. Madrasah Aliyah Mambaus Sholihin, e. Institut Keislaman Abdullah Faqih (INKAFA), f. Taman Kanak-kanak al-Qur'ân (TKQ), g. Madrasah Dinîyah ${ }^{16}$

\section{Aktivitas Pengembangan Bahasa Asing}

Mengingat bahwa Dwi Bahasa Asing (Arab dan Inggris) merupakan ikon market dari Mambaus Sholihin. Maka segala upaya dan usaha selalu diupayakan untuk memastikan bahwa pembelajaran bahasa terus berjalan dan berkembang. Diantaranya melalui program-program: (a) Kursus Bahasa Arab dan Bahasa Inggris, (b) Muḥâdathâh/Latihan berdialog, (c) Drill, pengayaan kosakata, (d) Latihan pidato bahasa Arab dan Inggris, (e) Latihan menulis (Inshâ)), (f) Latihan debat, dan (g) Lomba-lomba dalam bidang yang ada kaitan dengan keterampilan bahasa Arab dan Inggris. ${ }^{17}$

\section{Cabang-cabang Pesantren: Fakta Lingkungan Bahasa}

Dalam perkembangan Mambaus Sholihin terkini, pesantren ini berupaya terus mengembangkan wilayah dakwahnya, tidak hanya khusus di kabupaten Gresik saja, bahkan sudah sampai ke daerah-daerah luar Jawa. Langkah pengembangan ini, tidak lain sebagai inisiatif dan cita-cita pengasuh, Kiai Masbuhin untuk memperluas cakupan kemanfaatan yang bisa diambil oleh masyarakat dari keberadaan Mambaus Sholihin di wilayahnya, utamanya dalam bidang pendidikan dan dakwah Islam. Tercatat sampai tahun 2016, pesantren ini telah memiliki beberapa cabang pesantren yang tersebar di berbagai wilayah sebagaimana berikut: a. Mambaus Sholihin Cabang Blitar. ${ }^{18}$

Bernama Mambaus Sholihin 2 sebagai nomenklaturnya, pesantren yang menjadi cabang dari yayasan Mambaus Sholihin ini terletak di kabupaten Blitar. Selama kurang lebih 15 tahun, Mambaus Sholihin 2 telah banyak mengukir berbagai prestasi baik tingkat kabupaten, provinsi bahkan nasional dalam bidang pendidikan, utamanya soft skill dan kemahiran berbahasa Asing. Capaian tersebut membuktikan bahwa pesantren ini layak untuk diperhitungkan sebagai salah satu lembaga pendidikan Islam yang dapat dijadikan salah satu pilihan untuk menuntut ilmu. Selama ini Mambaus Sholihin memang benar-benar serius untuk

\footnotetext{
16 Ibid., 6-12.

17 Ibid., 12-13.

18 Lihat Pondok Pesantren Mambaus Sholibin 2 Blitar: Sekolah Berbasis Pesantren (Gresik: Majalah al-Fikrah edisi 88 Januari 2016 M/Rabiul Tsani 1437 H), 47-48.
} 
membantu pemerintah Indonesia dalam mencetak generasi bangsa yang tidak hanya pintar secara intelektual, tetapi juga juga cerdas secara spiritual dan emosional yang terwujud dari perilaku yang bermoral.

Setelah putra kedua, Agus Zainul Fajri, M.Ag lulus dari pesantren Mambaus Sholihin di Suci, Kiai Misbahuddin sowan kepada pengasuh pesantren itu, Kiai Masbuhin untuk minta restu mengembangkan madrasah al-Hidayah di Desa Sumber Baru Blitar yang ingin dirintis untuk dikembangkan menjadi pondok pesantren cabang dari pondok pesantren Mambaus Sholihin Gresik. Setelah mendapat izin untuk mengembangkan madrasah dari pengasuh, Kiai Masbuhin, Kiai Misbahuddin juga meminta restu dari Kiai Faqih Langitan.

Setelah restu dari kedua kiai karismatik tersebut diperoleh, lalu didirikanlah Mambaus Sholihin 2 di Blitar. Sistem penyelenggaraan pendidikan di Mambaus Sholihin 2 Blitar sebagaimana pondok pesantren umunya menerpakan sistem pendidikan boarding school (pemondokan). Siswa diharuskan berada di pondok dan mengikuti kegiatan pendidikan sepanjang hari, atau istilah barunya adalah full day school. Sistem ini diambil, lebih karena menginduk kepada Mambaus Sholihin Pusat. Dalam segi pengembangan bahasa Asing, di pesantren cabang ini juga mengadopsi dari apa yang sudah dikembangkan di pesatren pusat. Meskipun lingkungan bahasa Asingnya, masih belum terbentuk dengan baik sebagaimana di Mambasu Sholihin pusat.

b. Mambaus Sholihin Cabang Benjeng, Gresik. ${ }^{19}$

Pesantren ini adalah cabang ke 3 dari Mambaus Sholihin yang sistem pendidikan, manajemen dan pola pengasuhan santri masih mengikuti pola yang diterapkan dan dikembangkan di Mambaus Sholihin pusat. Pesantren ini berdiri sejak tahun 1994, yang awal mulanya hanya terdiri dari beberapa santri dari warga sekitar yang menuntut ilmu di sana dengan model kalongan (tidak menetap di pondok), sementara para pengajar di pesantren adalah beberapa orang yang didelegasikan dari pondok pusat. Mambaus Sholihin 3, selama perintisannya penuh cerita perjuangan, khususnya terkait sumber daya alam yang menjadi kebutuhan primer bagi pesantren, yakni air. Di wilayah ini, kalau musim kemarau akan mengalami krisis air, karena sulitnya ditemukan mata air di temapat tersebut. Dalam masa perintisan, salah satu sosok yang sangat

${ }^{19}$ Lihat Pondok Pesantren Mambaus Sholihin 3 Balongkepub Benjeng Gresik. (Gresik: majalah al-Fikrah edisi 88 Januari 2016 M/Rabiul Tsani 1437 H), 41-42. 
berpengaruh adalah bapak Achmad Rosyidin dan Bapak Achmad Fuady, kedua orang ini merupakan tokoh pemuda yang berpengaruh di Desa Balung Kepuh, dimana Mambaus Sholihin 3 berada.

Pada tanggal 4 Juli 2007 Mambaus Sholihin 3 diresmikan untuk lembaga formalnya, yakni MTS Mambaus Sholihin 3 Benjeng. Dalam kurikulum, cabang ini tentunya mengadopsi apa yang diberlakukan di Mambaus Sholihin pusat. Dalam segi lingkungan bahasa, di cabang ini belum terlihat signifikan perkembangannya sebagaimana dapat ditemukan di Mambaus Sholihin pusat. Hal ini lebih disebabkan tidak terpenuhinya unsur-unsur dalam membangun lingkungan bahasa Asing, khususnya bahasa Arab. Meskipun strategi pengayaan dalam pemerolehan bahasa, khususnya bahasa Arab dapat ditemukan sebagaimana di pusat, seperti pengajian kitab klasik berbahasa Arab, program kursus bahasa Asing dan kegiatan-kegiatan penunjang lainnnya. Hal ini lebih disebabkan belum terciptanya iklim yag baik dalam penggunaan bahasa Asing oleh santri, meskipun aturan sudah ada.

c. Mambaus Sholihin Cabang Balongpanggang, Gresik ${ }^{20}$

Pesantren ini merupakan cabang ke-5 yang dikembangkan oleh yayasan Mambaus Sholihin. Secara geografis pesantren ini terletak di Desa Balong Panggang Gresik. Kurang lebih $2 \mathrm{~km}$ sebelah barat Kantor Kecamatan Balong Panggang. Sedangkan dari jalur barat, berada di sebelah timur jalur Lamongan-Mojokerto. Pondok pesantren cabang ini diasuh oleh Ahmad Suchaimi, putra dari Kiai Masbuhin.

Pesantren ini secara fisik sebenarnya sudah dirintis sejak tahun 2011, namun baru beroperasi dari sisi kelembagaan dan organisasi pada tahun 2015. Dalam seremoni peletakan batu pertama pondok pada tahun 2009, hadir kala itu, Kiai Faqih Langitan, guru dari Kiai Masbuhin. Pada tahap awal, santri di cabang Mambaus Sholihin ini merupakan santri yang dipindahkan dari Mambaus Sholihin pusat. Sebab, keterbatasan daya tampung di pesantren, sementara membludaknya calon santri, maka diputuskan untuk menempatkan santri tingkat awal di cabang ini. Di tahun kedua setelah resmi secara kelembagaan proses pembelajaran terjadi di cabang ini, lebih dari 86 santri telah bermukim disana.

Sebab alasan karena memang mayoritas santri di tempat tersebut adalah santri tingkat awal, maka lingkungan bahasa Asing masih didapati

20 Lihat Pondok Pesantren Mambaus Sholibin 5 Kedungsumber Balongpanggang Gresik (Gresik: majalah al-Fikrah edisi 88 Januari 2016 M/Rabiul Tsani 1437 H), 45-46. 
dalam proses pembentukan. Hal ini terlihat melalui program dan strategi yang dikembangkan mirip dengan apa yang ditemukan di Mambaus Sholihin pusat. Pengurus pesantren yang memang diambil dari santrisantri senior yang sudah terbentuk keterampilan berbahasa Asing, baik Arab maupun Inggris sengaja diajak oleh Suchaimi, pengasuhnya ikut terlibat dalam pembentukan lingkungan bahasa Asing di tempat tersebut. Mereka ini menjadi tunas dan sumber bahasa bagi santri-santri baru. Mereka menjadi agen untuk membiasakan penggunaan bahasa Asing dalam kegiatan sehari-hari di cabang ini.

d. Mambaus Sholihin Cabang Masoi, Ambon ${ }^{21}$

Pondok Mambaus Sholihin 4 terletak di Kota Masohi. Tepatnya di Desa Banda Baru Kecamatan Amahai Kabupaten Masohi. Pondok ini berjarak kurang lebih $20 \mathrm{~km}$ dari pusat kota. Untuk menuju ke sana hanya bisa diakses menggunakan kendaraan pribadi seperti mobil ataupun motor. Jalannya sudah beraspal meskipun saat akan memasuki desanya masih banyak lubang dan retakan-retakan yang cukup besar di sepanjang jalan.

Perintis pertama ialah Abdus Salam pada tahun 1996. Ketika terjadi kerusuhan di Ambon, Mambaus Sholihin 4 sempat mati suri. Baru setelah kerusuhan mereda, Suwar Nur Alam mencoba menghidupkan aktivitas di cabang Masoi ini. Nur Alam adalah putra daerah yang telah lama menimba ilmu di Mambaus Sholihin pusat sejak Madrasah Ibtidaiyah hingga tamat pendidikan di tingkat Perguruan Tinggi.

Pada akhir tahun 2009, Hadi Purwowidodo dan Abdul Ghofur didelegasikan oleh KH Masbuhin untuk membantu pengembangan yang sudah dirintis oleh Suwar Nur Alam, hingga akhirnya melanjutkan pengasuhan di cabang ini sampai Syamsul Arifin menggantikan mereka berdua. Boleh dibilang, cabang satu ini yang paling sulit berkembang. Hal ini semata alasan demografi yang jauh dari pesantren pusat, sehingga pemantauan dan pembinaannya menjadi lamban dan sering mengalami pasang surut. Maka, di cabang ini tidak ditemukan lingkungan bahasa Asing yang mulai dirintis. Sebab, tujuan pendidikannya lebih pada pendalaman keislaman, utamanya al-Qur'ân.

${ }^{21}$ Lihat Lentera Islam di Timur Indonesia Pondok Pesantren Mambaus Sholibin Cabang Masobi Maluku Tengah (Gresik: majalah al-Fikrah edisi 88 Januari 2016 M/Rabiul Tsani 1437 H), 54-55. 
e. Mambaus Sholihin Cabang Bali ${ }^{22}$

Mambaus Sholihin 6 berada di kepulauan Bali dirintis oleh Ahmad Sariaman pada tahun 2011. Fondasi dasarnya berawal dari kegiatan istighosah yang saat itu masih dilakukan di rumahnya sendiri. Di samping itu, Sariaman juga mengajar al-Qur'ân dan mengajar materi keislaman kepada masyarakat Pengambengan, temapat ia tinggal. Sebelumnya, Sariaman pernah berada di Jawa Tengah selama 2 tahun untuk membantu pengembangan di salah satu pesantren. Dalam masa pengabdiannya, beliau di cari oleh Kiai Masbuhin untuk memintanya pulang ke tanah kelahirannya, Bali guna mendirikan Pondok Pesantren di sana.

Gurunya itu memberi petunjuk secara khusus kepada Sariaman melalui dawuh-nya (ucapan), lek gak muleh gak tak dongakno maneh lan gak take aku santriku (kalau tidak pulang ke rumah tidak saya doakan lagi serta tidak aku anggap sebagai santriku). Mendengar ucapan sang guru, Sariaman seketika mematuhi apa yang sudah disampaikan gurunya karena takut akan tidak mendapat doa dan berkah guru, apalagi ilmu yang selama ini ia terima darinya. Maka, pada Tahun 2010 pulanglah Sariaman ke Bali.

Di cabang 6 ini, lingkungan bahasa Asing juga mulai dirintis oleh pengelola, sebab kesadaran akan pentingnya menguasai bahasa internasional untuk bisa bersaing dalam banyak hal, termasuk secara khusus mewujudkan umat muslim yang bermartabat dalam kancah global. Semesntara, bahasa Arab memang harus dikuasai untuk mendalami ilmu keislaman. Tetapi, karena baru tahap merintis, lingkungan bahasa Asing yang diharapakan belum menunjukkan perkembangan yang signifikan jika dibanding dengan Mambaus Sholihin di Blitar, apalagi pusat.

f. Cabang Bintan Kepulauan Riau

Cabang Mambaus Sholihin Bintan, awal berdirinya ditandai dengan seremoni peletakkan batu pertama pada 4 Januari 2015 oleh Kiai Masbuhin. Pondok cabang ini terletak di wilayah utara negara Indonesia yang menjadi perbatasan dengan negara Malaysia dan Singapura. Tepatnya, di Jl. Manggar, Kampung Bugis, RT. II/RW. I, Tanjung Uban Utara Kecamatan Bintan Utara Kabupaten Bintan, Kepaulauan Riau.

22 Lihat Menyapa Embun Pagi di Pesantren Mambaus Sholibin Cabang Bali (Gresik: Majalah al-Fikrah edisi 88 Januari 2016 M/Rabiul Tsani 1437 H), 37-38. 
Pada awalnya, lembaga yang ada hanya TPQ. Kemudian pada tahun selanjutnya mulai dibuka pendidikan tingkat Sekolah Menengah Pertama (SMP). Santri pertama yang masuk berjumlah 21 anak. Dan mereka wajib mukim dipondok karena program yang diterapkan adalah sekolah berbasis pesantren. Mereka juga wajib mengikuti kegiatan yang ada dipondok dan mengikuti aturan yang ada dipondok.

Pondok cabang Bintan sendiri dipimpin oleh Ahmad Nukhan. Ia bersama tenaga pengajar yang lain bertugas mengawasi santri dalam melakukan kegiatan sehari-hari. Secara umum kegiatan di pondok cabang masih berkiblat kepada pondok pusat. Untuk saat ini pembelajaran alQur'ân yang lebih diperhatikan. Sedangkan santri wajib berbahasa insya Allah dimulai pada bulan Januari 2016. Untuk model sekolah berbasis pesantren berkiblat pada pondok Mambaus Sholihin 2 cabang Blitar karena hanya di sana yang mendirikan SMP. Selain tenaga pengajar yang kebanyakan dari pusat, pondok cabang juga mengambil tenaga pendidik dari beberapa pesantren dan guru non-pesantren untuk kegiatan ekstrakurikuler, termasuk didalamnya pembelajaran bahasa asing.

Dari paparan fakta kondisi di Mambaus Sholihin tentang bangunan sistem pembelajaran yang mengarah pada terbentuknya lingkungan bahasa Asing, dalam tema ini dikhususkan pada bahasa Arab, dapat ditemukan bahwa terdapat suatu fakta fenomenologis yang menunjuk kan adanya modalitas yang sama di pondok pusat dan cabang-cabang Mambaus Sholihin terkait pengembangan bahasa melalui pembentukan lingkungan bahasa, paling tidak dari sisi sumber belajar, penggunaan kitab klasik keislaman sebagai sumber memahami ilmu-ilmu khas Islam; figh, akhlak, nahwu, sharaf, dan lainnya, menyajikan satu pemahaman tentang kondisi yang berpotensi terbentuknya lingkungan bahasa.

Selain itu, tenaga pengajar yang sebagian besar adalah alumni dari pondok pusat dan punya keterampilan dalam berbahasa Arab, apalagi didukung dengan keberadaan alumni yang pernah belajar di negaranegara, dimana bahasa Arab menjadi bahasa native penduduknya, merupakan modal yang sangat cukup terkait pembentukan lingkungan bahasa Arab. Ditambah lagi kegiatan informal, seperti kursus intensif bahasa Arab, program muḅâdathah (percakapan), muḥ̂ạarah (pidato), masrâhîyah (drama), dan program pendukung lainnya, mestinya hal tersebut menjadi faktor utama yang menunjukkan keberhasilan Mambaus 
Sholihin dan cabang-cabangnya, menciptakan iklim yang kondusif dalam ruang lingkup lingkungan bahasa Arab.

\section{Pemondokan Mahasiswa}

Pemondokan mahasiswa di Mambaus Sholihin merupakan bagian dari pemondokan yang berada di dalam pesantren, peruntukannya untuk mahasiswa putra yang sedang menempuh studi di Institut Keislaman Abdullah atau Inkafa, pemondokan ini mempunyai nama khusus Ribât Abdullah Faqih dan baru ditempati pada tahun 2013. Hampir seluruh mahasiswa Inkafa bertempat tinggal di pemondokan tersebut karena ketentuan pesantren bahwa mahasiswa yang berasal dari luar desa Suci harus menetap di pemondokan. Santri mahasiswa yang berdomisili di pemondokan berasal dari berbagai latar belakang dan ragam asal daerah, dari sudut pandang itu lingkungan ini ditempati oleh masyarakat yang heterogen.

Ada berbagai aktivitas dilaksanakan di pemondokan, mulai dari mengaji di hadapan kiai (sorogan), belajar mandiri (mutâla'ah, salat berjemaah hingga kegiatan pengembangan bahasa asing (bahasa Arab dan Inggris) seperti kursus dan lain sebagainya. Maka dalam ruang lingkup tema bahasan, pemondokan merupakan keseluruhan dari lingkungan bagi santri mahasiswa, baik lingkungan bahasa, lingkungan belajar dan lingkungan sosial, serta lingkungan lain yang turut andil membentuk karakter dan perilaku santri.

Tapi kondusifnya lingkungan bahasa Arab di pemondokan untuk santri yang menempuh jenjang pendidikan tinggi ini justru menunjukkan fakta terbalik dari, gambaran umum tentang lingkungan bahasa Arab di Mambaus Sholihin. Kenyataan yang tergambar, bahwa santri mahasiswa justru memiliki kesadaran yang minim untuk menggunakan bahasa Arab atau Inggris dalam berkomunikasi sesama temannya, beda dengan di pemondokan yang ditinggali oleh santri-santri pada tingka pendidikan di bawahnya, bahkan di tingkata Tsanawiyah. Kondisi yang demikianlah yang mendorong penulis untuk melakukan development research di lokus ini. Tentu, dengan tujuan dapat mengungkap masalah dan memberi solusi penanganannya.

\section{Lingkungan Bahasa di Pemondokan Mahasiswa}

Untuk menyampaikan hasil kajian melalui Focus Group Discussion (FGD) yang dilakukan bersama subjek, ada beberapa problematika yang muncul terkait fakta yang ditemukan pada lingkungan bahasa di Ribât. 
Abdullah Faqih Mambaus Sholihin. Dari masalah-masalah yang telah dilakukan proses verifikasi, kemudian ditindaklanjuti dengan suatu perspektif cara pemecahannya, problematika itu dapat dirumuskan ke dalam beberapa poin berikut:

\section{Heterogenitas Subjek Bahasa}

Keadaan sosial-bahasa di kalangan santri mahasiswa sangatlah heterogen. Hal ini berdasarkan pada keragaman latar sosiologis daerah subjek bahasa di temapt itu. Santri mahasiswa di pemondokan khusus mahasiswa (Ribât Abdullah Faqih) berasal dari berbagai pulau dan etnis di Nusantara; Jawa, Madura, Sumatra, Kalimantan, Maluku, Papua, bahkan ada yang berasal dari negara Malaysia. Maka, asal daerah subjek dan kemajemukan latar sosial-bahasa berpengaruh terhadap tingkat penguasaan dan kemahiran berbahasa Asing sebagaimana yang sudah dikaji melalui observasi oleh penulis. Misalnya pada kemahiran pengucapan, labjah (dialek/logat) daerah sering menjadi kendala bagi santri untuk mengucapkan bahasa Arab yang fuṣah (baku). Logat daerah masih sangat kental didapati dalam percakapan bahasa Arab di antara subjek.

Selain logat daerah, latar pendidikan subjek yang beragam juga menjadi fokus penulis. Santri di Ribât Abdullah Faqih tidak hanya lulusan dari lembaga pendidikan yang sama. Meskipun mayoritas dari mereka adalah lulusan dari Pesantrean Mambaus Sholihin, tapi jenjang studinya beragam. Hampir 70 persen diantaranya memulai belajar di Mambaus Sholihin dari jenjang Aliyah. 25 persen dari jenjang Tsanawiyah dan sisanya dari lembaga pendidikan luar pesantren. Kondisi ini, dalam hemat penulis juga menjadi pertimbangan dalam studi ini

Heterogenitas yang telah diurai oleh penulis untuk mendeskripsikan kondisi faktual dari lingkungan bahasa yang akan dijelaskan, menjadi fokus penulis dikarenakan sebagai titik pijak dari development action (aksi pengembangan) yang direncanakan sehingga punya dampak signifikan dalam upaya membangun lingkungan bahasa yang diharapkan.

\section{Skema Pembentukan al-Bîah al-‘Arabîyah}

Pembentukan lingkungan bahasa Arab di Ribât Abdullah Faqih Mambaus Sholihin tak luput dari kendala-kendala yang dihadapi. Penulis telah melakukan inventarisasi yang dikelompokkan ke dalam masalah dan solusi sebagaimana berikut:

a. Kebutuhan terhadap tim penggerak bahasa. 
Pembentukan lingkungan bahasa tentu dibutuhkan tim penggerak yang secara langsung bertugas mengelola pembentukan lingkungan bahasa Arab. Permasalahan tersebut disampaikan oleh sebagian santri yang tinggal di pemondokan, mengingat sampai saat ini belum ada tim yang dimaksud. Untuk memecahkan masalah ini, subjek mengagendakan pertemuan bersama yang melibatkan seluruh subjek di pemondokan untuk membentuk tim penggerak bahasa asing (Arab dan Inggris). Dari pertemuan itu, terbentuklah tim penggerak bahasa asing. Selain itu, pertemuan tersebut juga menjadi momentum pencerahan dan pemberian stimulan bagi seluruh subjek untuk berkomitmen dan mendukung proses pembentukan lingkungan bahasa Arab di Ribât Abdullah Faqih.

Tim penggerak bahasa yang telah terbentuk, bertugas mengoptimalisir penggunaan bahasa Asing di lingkungan asaram, selain itu meraka juga diharuskan menegakkan aturan-aturan disiplin berbahasa yang sudah ditetapkan secara bersama. Menggagas ide-ide kreatif dan inovatif yang berupa kegiatan-kegiatan untuk mendukung terciptanya lingkungan bahasa, juga menjadi tanggung jawab dari tim penggerak bahasa. Dalam menjaga menegakkan aturan di lingkungan bahasa Arab, mereka akan selalu melakukan upaya pengawasan untuk mencegah mahasiswa menggunakan bahasa Daerah atau Indonesia dalam komunikasi sehari-hari.

Sementara program-program penunjang, misalnya mengajak atau menyerukan (kampanye) kepada seluruh subjek di lingkungan bahasa agar selalu menggunakan bahasa Arab haurs lebih digalakkan, juga dengan pengayaan kosakata bahasa Arab dan Inggris pada setiap hari harus dilakukan dengan konsisten, mengupayakan pelabelan atau papanisasi pada setiap atribut atas benda dan fasilitas di lingkungan bahasa tidak luput untuk dilakukan dalam waktu dekat. Hal ini dimaksudkan agar subjek bahasa semakin terbiasa dengan kosa kata keseharian dalam bahasa yang dimaksud, sekaligus menstimulasi subjek untuk menggunakan bahasa Arab karena dipermudah oleh keberadaan label-label berbahasa Arab dan Inggris.

Di samping tugas tersebut, tim juga secara terus menerus melakukan pengembangan penguasaan bahasa Arab di lingkungan bahasa dengan berbagai kegiatan yang mendukung kelestarian lingkungan bahasa Arab. Tim tidak sendiri dalam operasionalnya, karena mereka juga akan dibantu oleh pengurus departemen bahasa Arab dalam Organisasi Santri Pondok Pesantren Mambaus Sholihin (OSPPMS) dan dibina langsung oleh 
markaz al-lughah (pusat bahasa), yang beranggotakan para guru dan pimpinan di pesantren.

Setidaknya ada beberapa stakeholders yang bisa dilibatkan dan memiliki kepentingan yang sama untuk membentuk lingkungan bahasa di Ribât Abdullah Faqih, yaitu sebagai berikut:

1) Markaz al-lughah. Lembaga pusat pengembangan bahasa yang dibentuk oleh Pondok Pesantren adalah bertanggung jawab atas kondisi pengembangan bahasa Asing (Arab dan Inggris) di seluruh wilayah pesantren, baik di satuan-satuan pendidikan formal mulai dari Raudlatul Athfal, Madrasah Ibtidaiyah, Madrasah Tsanawiyah, Madrasah Aliyah dan Perguruan Tinggi maupun di pemondokanpemondokan santri. Kedudukan lembaga pusat pengembangan bahasa ini adalah sebagai pembina, pendorong dan kontrol pelaksanaan lingkungan bahasa di seluruh pemondokan pondok pesantren Mambaus Sholihin. Lembaga ini akan terus melakukan monitoring (pengawasan), supervisi dan evaluasi terhadap proses dan implementasi program pembentukan lingkungan bahasa di Ribât Abdullah Faqih.

2) Departemen Bahasa OSPPMS. Lembaga ini merupakan pelaksana teknis kegiatan pengembangan bahasa di pesantren yang akan menjadi mitra kerja tim penggerak di lingkungan Ribât. Abdullah Faqih . Lembaga ini diisi oleh para mahasiswa yang kompeten di bidang pengembangan bahasa Arab. Di antar tugas pokonya adalah memberikan stimulan bagi santri mahasiswa dalam mewujudkan terbentuknya lingkungan bahasa Arab di asarama mahasiswa. Hal itu dilakukan misalnya dengan memberikan tugas kepada mahasiswa untuk melakukan pembinaan dan pembelajaran bahasa Arab kepada santri-santri yang lebih muda. Dengan tugas tersebut, mahasiswa dapat dengan mudah mengalami pembiasaan berbahasa Arab. Sebab karena tanggung jawab itu diharapkankan memberikan stimulan dan dorongan kepada mahasiswa tingkat atas untuk meningkatkan kemampuan bahasa mereka sebelum menjalankan tugas pembinaan dan pembelajaran bagi mahasiswa di tingkat bawahnya.

3) Tim penggerak bahasa Arab di lingkungan pemondokan. Tim ini merupakan tonggak keberlangsungan dalam proses pembentukan lingkungan bahasa artifisial, yang secara langsung terlibat dalam upaya pemerolehan, pembiasaaan dan penegakkan disiplin bahasa 
yang secara konsisten dan kontinyu sehingga terciptalah lingkungan bahasa Arab. Di antara yang dapat dilakuakan oleh tim ini misalnya menyampaikan ajakan untuk menggunakan bahasa Arab di Ribât Abdullah Faqih, menata dan mengelola kegiatan yang mendukung pembentukan bahasa Arab seperti kursus bahasa Arab, pengayaan kosakata dan ungkapan-ungkapan berbahasa Arab, latihan berbicara dalam bahasa Arab dan lain sebagainya. Juga unutk penegakan peraturan disiplin bahasa, mereka harus melakukan pengawasan secara langsung kepada mahasiswa di pemondokan dengan cara keliling-keliling. Yang tak kalah penting, mereka ini juga punya tanggung jawab mengidentifikasi dan mengakomodir permasalahanpermasalahan dalam jalannya lingkungan bahasa Arab, bila mendapati permasalahan yang sulit mereka pecahkan maka disampaikan kepada departemen bahasa dan markaz al-lughah.

b. Bahasa Arab belum menjadi bahasa komunikasi keseharian.

Sebagaimana dalam bahasan sebelumnya dijelaskan bahwa mayoritas mahasiswa bisa menggunakan bahasa Arab sebagai bahasa pengantar dalam komunikasi sehari-hari, akan tetapi mereka merasa susah memulai dan merasa kurang bebas saat menggunakan bahasa Arab. Dari sini kemudian perlu dilakukan kajian bersama santri mahasiswa untuk mendalami fenomena yang didapat melalui diskusi, yang diawali dengan mengajukan tiga pertanyaan berikut:

Pertama, kenapa komunitas di Ribât Abdullah Faqih tidak menggunakan bahasa Arab?; Kedua, kenapa berbicara dengan menggunakan bahasa Arab dianggap kurang bebas dan merasa terkekang?; dan ketiga, kapan bisa dengan mudah memulai kembali berbicara dengan menggunakan bahasa di pemondokan?

Dari pertanyaan-pertanyaan di atas setelah dilakukan sharing group muncul simpulan sebagai berikut:

Pertama, santri mahasiswa yang rata-rata telah bertempat tinggal di pesantren beberapa tahun sebagian besar mereka telah bertempat tinggal selama enam tahun, sebagian lagi tiga tahun dan sebagian kecil baru tinggal di pesantren semenjak menjadi mahasiswa. Selama mereka tinggal di pesantren, mereka telah mendapatkan berbagai pola penguatan bahasa Arab bahkan saat mereka masih belajar di Madrasah Tsanawiyah atau Aliyah pesantren kala itu dengan berbagai aturan sangat didorong untuk 
berbicara menggunakan bahasa Arab, kemudian menjadi terbiasa menggunakan bahasa Arab sebagai komunikasi sehari-hari.

Di pesantren pengembang bahasa Asing (Arab dan Inggris), pesantren telah mewajibkan seluruh penghuni untuk menggunakan bahasa Asing akan tetapi sebagian santri tidak mematuhi ketentuan tersebut. Maka Perlu semangat bersama untuk meningkatkan intensitas penggunaan bahasa Asing, membangkitkan kembali semangat dan gerakan berbahasa asing secara serentak oleh seluruh santri mahasiswa dengan penyadaran kembali terhadap titah pesantren dan urgensi penggunaan bahasa Asing, termasuk bahasa Arab sebagai bahasa komunikasi dan penunjang di masa mendatang ketika mereka berada di dunia kerja, selain itu juga mendukung dalam kajian keagamaan, mendukung kecakapan dalam berbahasa Arab maupun faktor lainnya.

Kedua, ketika santri mahasiswa yang menetap di pemondokan diajak menggunakan bahasa Arab mereka beranggapan kurang bebas dan terkekang. Itu karena mereka beranggapan akan diperlakukan sebagaimana dulu ketika tinggal di pemondokan santri pada tingkat pendidikan sebelumnya yang dipaksa untuk menggunakan bahasa Arab, diawasi oleh pengurus, ditetapkan punishment (hukuman) ketika melanggar dan reward (hadiah) ketika mereka berprestasi dalam menggunakan bahasa Arab. Padahal mereka tinggal di Ribât Abdullah Faqih yang penggerak bahasanya adalah teman sebaya mereka, namun tetap dibimbing dan dikontrol oleh para guru. Dengan begitu sebenarnya lingkungan bahasa Arab dapat dijalankan dengan tanpa ada paksaan dan perasaan terkekang. Aturan dan ketentuan dapat mereka sepakati bersama atau bahkan tanpa aturan dan kemudian dijalankan dengan sadar secara bersama-sama.

Ketiga, pertanyaan kapan dengan mudah menggunakan bahasa Arab sebenarnya pertanyaan yang sederhana tapi mengandung konsekuensi yang besar bagi komunitas. Sebenarnya jawaban dari pertanyaan itu ialah kapan pun bisa dimula untuk berbahasa Arab. Tetapi kebanyakan subjek menghendaki waktu yang tepat setelah semua masyarakat pemondokan mengetahui dan menyadari akan adanya lingkungan bahasa Arab yang dibentuk dan dikembangkan berdasarkan pada sebuah konsensus bersama.

c. Kegiatan pengembangan bahasa Arab yang belum masif. 
Di samping permasalahan yang telah diuraikan sebelumnya, ada masalah lain yang menurut santri mahasiswa juga perlu untuk dikaji akar masalahnya, sehingga dapat dipecahkan secara bersama melalui kegiatan diskusi. Masalah itu adalah masih kurangnya kegiatan-kegiatan penunjang pengembangan bahasa Asing, yang diprogramkan oleh markaz lughah, departemen bahasa dan tim penggerak. Meskipun ada tapi kegiatan itu belum bisa memotivasi para subjek bahasa untuk secara sadar mewujudkan lingkungan bahasa Arab yang dicitakan bersama. Banyak dari kegiatan-kegiatan pengembangan bahasa itu, dipandang mahasiswa belum memberikan dorongan yang besar untuk mewujudkan cita-cita terciptanya lingkungan bahas asing yang kondusif, maka perlu ada kegiatan pendukung yang secara terus menerus bisa menggelorakan kesadaran bersama subjek bahasa di lingkungan itu untuk menggunkan bahasa Arab dalam komunikasi antarteman, berdiskusi dan sebagainya.

d. Keterlibatan seluruh stakeholders yang minim.

Masalah lain yang didapatkan dalam FGD adalah belum terlibatnya masing-masing stakeholders secara menyeluruh dan terkordinasi. Komunitas santri mahasiswa memandang bahwa ada banyak sumber daya manusia yang belum dilibatkan dalam pembentukan lingkungan bahasa, ada banyak tenaga pengajar lulusan Universitas Timur Tengah dan lulusan Perguruan Tinggi Dalam Negeri yang mumpuni untuk dilibatkan untuk memberikan dukungan dan penguatan. Bahkan pesantren dan kampus juga diharapkan ikut selalu mendorong.

Secara kelembagaan, pendidikan tinggi di pesantren punya kewajiban untuk patuh terhadap aturan pesantren sebagai innstitusi yang membawahinya, termasuk terlibat dalam pembentukan lingkungan bahasa Arab di Ribât Abdullah Faqih. Karena pengembangan bahasa Arab di kampus juga menjadi bagian sasaran markaz al-lughah, maka dengan begitu sumber daya manusia yang dimiliki juga bisa dilibatkan. Ada beberapa program penguatan yang mendukung pembentukan dan kelestarian lingkungan bahasa Arab, diantaranya melakukan reformulasi kegiatan pembelajaran bahasa Arab yang semula dilakukan dalam pembelajaran formal di perkuliahan dengan distribusi mata kuliah bahasa Arab pada tiga semester atau enam bobot kredit menjadi model kursus intensif bahasa Arab selama setahun atau dua semester dengan bobot setara enam semester, sehingga diharapkan dari reformulasi yang 
dilakukan ada proses penguatan kemampuan berbahasa Arab bagi mahasiswa.

Keterlibatan sumber daya manusia yang dimaksud adalah sumber daya manusia yang memiliki kompetensi komunikatif bahasa baik lisan maupun tulis sehingga mereka juga dapat menjadi model aktivitas kebahasaan.

e. Kemampuan penguna bahasa Arab belum merata.

Permasalahan ini unik, satu sisi mahasiswa baru memiliki semangat yang tinggi dalam belajar dan pengembangan bahasa Arab meskipun mereka memiliki modal yang sedikit, sisi yang lain mahasiswa yang beberapa tahun telah bertempat tinggal di pesantren memiliki semangat yang rendah padahal mereka memiliki modal yang cukup untuk menghidupkan lingkungan bahasa Arab.

Bagaimana dua sisi tersebut dapat menjadi hubungan yang mutualis, yakni santri mahasiswa lama dapat termotivasi menggunakan bahasa Arab karena mahasiswa baru, sementara mahasiswa baru dapat belajar dari mahasiswa lama untuk meningkatkan perbendaharaan kata Arab dan berlatih berbahasa dalam kegiatan sehari-hari. Istilah ini disebut dengan motivasi internal dan eksternal yang saling mengikat dan mendukung. Rettob menjelaskan bahwa hasil penelitian yang dilakukan oleh Gardner dan Lambert di Kanada tentang sikap dan motivasi dalam belajar bahasa kedua memberikan kesimpulan bahwa intelegensi dan bakat bukan merupakan faktor tunggal tetapi masih ada hal yang berpengaruh yaitu motivasi ekstrinsik atau bisa juga disebut motivasi intergratif, dan motivasi ini lebih banyak berperan dibandingkan motivasi intrinsik. 23

Untuk membina mahasiswa baru agar memiliki kemampuan berbahasa Arab secara akseleratif maka mereka dibimbing dalam kursus dan bila dalam praktik komunikasi menggunakan bahasa Arab mendapati kesulitan maka dianjurkan meminta bimbingan kepada mahasiswa yang lama. Dengan begitu mahasiswa yang lama akan termotivasi dan merasa malu bila tidak menggunakan bahasa Arab dalam komunikasi keseharian, maka dengan semangat yang tinggi tersebut mereka akan dengan cepat beradaptasi dan mengejar ketertinggalan.

f. Kesadaran penggunaan bahasa Arab yang rendah.

23 Theresia Rettob, "Motivasi dalam Proses Pemerolehan Bahasa Kedua" dalam Nurhadi dan Roekhan Dimensi-dimensi dalam Belajar Bahasa Kedua (Bandung: Sinar Baru Bandung dan YA3 Malang, 1990), 152. 
Kesadaran dalam menggunakan bahasa Arab sebagai bahasa komunikasi sehari-hari merupakan hal yang sangat penting, karena sumber utama kebekuan dan jalannya bahasa adalah dari penuturnya. Kalau penuturnya memiliki kesadaran yang rendah, maka bahasa beku. Sebaliknya, bila penuturnya selalu menggunakan bahasa maka bahasa tersebut menjadi hidup.

Membangun kesadaran penutur merupakan hal yang tidak mudah, butuh upaya-upaya cerdas, telaten dan terus menerus. perlu melakukan pendekatan terus menerus kepada masyarakat pengguna bahasa agar memiliki kesadaran yang tinggi, hal itu dilakukan oleh tim penggerak khusus lingkungan bahasa Arab, dibantu oleh pengurus pondok departemen bahasa organisasi santri Mambaus Sholihin, dibina dan dikontrol oleh para guru dan markaz al-lughah, kemudian diperkuat dengan kegiatan-kegiatan penunjang.

Dalam kegiatan-kegiatan penunjang tersebut, santri mahasiswa diberi stimulus tentang pentingnya penggunaan bahasa Arab untuk pembelajar dan pengkaji kajian keislaman, anjuran melalui dalil-dalil Agama dan romantisme keberadaan lingkungan bahasa Arab yang dulu pernah cemerlang di pesantren. Pesantren ini pernah mengalami masa keemasan dalam melestarikan lingkungan bahasa Arab sehingga pesantren ini dikenal dengan pesantren bahasa.

Kesadaran mahasiswa menjadi hal yang sangat penting, karena ketika kesadaran tumbuh dalam diri mahasiswa yaitu kesadaran pentingnya praktik bahasa Arab sebagai media komunikasi, maka akan tercipta lingkungan bahasa Arab, tapi sebaliknya jika mahasiswa tidak memiliki kesadaran untuk menggunakan bahasa Arab sebagai media komunikasi sehari-hari maka lingkungan bahasa Arab yang diinginkan akan sulit terealisir.

Secara garis besar, faktor yang melatarbelakangi jalannya lingkungan bahasa meliputi faktor Linguistik dan non-linguistik, faktor linguistik meliputi kemampuan dalam kompetensi dan performansi bahasa oleh subjek, ketika dua hal tersebut dimiliki oleh subjek, maka tinggal melakukakan dorongan-dorongan melelui faktor non-lingusitik yang juga tak kalah sulitnya. Di antara faktor non-linguistik yang memberika peran bermakna dalam jalannya lingkungan bahasa adalah:

Pertama, faktor psikis. Dalam pengelolaan lingkungan diperlukan motivasi dan minat bagi seluruh stakeholders yang ada di dalamnya. Dua 
hal itu yang mendorong subjek untuk penuh semangat dalam menjalankan lingkungan Bahasa.

Kedua, faktor pengelolaan. Diperlukan pengelolaan yang efektif dan efesien dalam lingkungan bahasa sehinggga lingkungan bahasa dapat berjalan secara tertatur dan baik. Dimulai dari perencanaan, pengorganisasian, pelaksanaan sampai pada kegiatan evaluasi. Pengelolaan dilakukan oleh pengelola yang memahami karakter subjek lingkungan bahasa.

Ketiga, faktor sosial. Faktor ini meliputi heterogenitas subjek lingkungan bahasa, masyarakat yang berada di sekitar lingkungan bahasa dan dukungan berbagai pihak yang ada termasuk tokoh yang yang ada lingkungan Bahasa.

Keempat, faktor perangkat. Perangkat dalam lingkungan bahasa dapat berupa perangkat lunak dan perangkat keras, perangkat lunak misalnya berupa sistem, aturan dan kurikulum pengembangan bahasa, sedangkat perangakat keras bisa meliputi sarana dan prasarana pendukung lingkungan bahasa seperti papanisasi, labeling berbagai benda yang ada lingkungan dan lain sebagainya.

\section{Catatan Akhir}

Dari uraian yang telah dipaparkan, bahwa kerja partisipatoris yang bertujuan membentuk lingkungan bahasa Arab ini sampai pada beberapa simpulan yang mewakili dari keseluruhan fenomena ynag dihadapi oleh subjek di Ribât Abdullah Faqih melalui Forum Group Discussion (FGD), diantaranya, 1) perlu terus dilakukan upaya kreatif dan inovatif untuk mendorong penggunaan bahasa Arab sebagai bahasa pengantar keseharian, sehingga perasaan bahwa belajar bahasa Arab itu sulit, akan dengan sendirinya dihilangkan oleh kebiasaan; 2) diperlukan penggerak bahasa yang bertanggung jawab atas jalannya lingkungan bahasa Arab di Ribât Abdullah Faqih; 3) diperlukan kegiatan-kegiatan penunjang untuk pengembangan bahasa Arab yang dapat memotivasi jalannya lingkungan bahasa, baik kegiatan-kegiatan rutin maupun kegiatan yang sifatnya insidental; 4) diperlukan keterlibatan stakeholders yang menetap di Ribât Abdullah Faqih untuk saling mendukung dan memberi kontribusi dalam pmmbentukan lingkungan bahas asing yang baik; dan 5) secara psikis, perlu dibangun kesadaran dan semangat tinggi dalam diri subjek bahasa di di Ribât Abdullah Faqih untuk konsisten dengan cita-cita dan konsensus bersama. 


\section{Daftar Rujukan}

Dalyono, M. Psikologi Pendidikan. Jakarta: Rineka Cipta, 2012.

Effendi, Ahmad Fuad. Metodologi Pengajaran Bahasa Arab. Malang: Misykat, 2005.

Hasan, Tamam. al-Tamhîd fî Iktisâb al-Lughah al-'Arabîyah li Ghayr Nâtiqîn

bihâ. Makkah: Wizârat al-Ta 'lîm al-'Âlî Jâmi'at Umm al-Qurâ, 1984.

Kilas Sejarah Mambaus Sholibin. Gresik: al-Fikrah edisi 88 Januari 2016 M/Rabiul Tsani $1437 \mathrm{H}$.

Lentera Islam di Timur Indonesia Pondok Pesantren Mambaus Sholibin Cabang Masobi Maluku Tengah. Gresik: majalah al-Fikrah edisi 88 Januari 2016 M/Rabiul Tsani $1437 \mathrm{H}$.

Martinis. Lingkungan Belajar Berkulitas, dalam http://martinis1960. wordpress.com/2011/02/04/lingkungan-belajar-berkualitas/ diakses pada 15 Januari 2015.

Marzuqi. Dawrat al-Lughâwîyah fî Tarqîyat al-Lughah al-'Arâbîyah. Makalah disampaikan dalam Seminar di UIN Mualana Malik Ibrahim Malang, 2001.

Menyapa Embun Pagi di Pesantren Mambaus Sholibin Cabang Bali. Gresik: Majalah al-Fikrah edisi 88 Januari 2016 M/Rabiul Tsani 1437 H.

Novrianti. Pemanfaatan Lingkungan sebagai Sumber Belajar, dalam http://sweetyhome.wordpress.com, diakses 15 Januari 2015

Nurhadi dan Roekhan. Dimensi-Dimensi dalam Belajar Bahasa Kedua. Bandung: Sinar Baru Bandung, 1990.

Pondok Pesantren Mambaus Sholibin 2 Blitar: Sekolah Berbasis Pesantren. Gresik: Majalah al-Fikrah edisi 88 Januari 2016 M/Rabiul Tsani 1437 $\mathrm{H}$.

Pondok Pesantren Mambaus Sholibin 3 Balongkepub Benjeng Gresik. Gresik: majalah al-Fikrah edisi 88 Januari 2016 M/Rabiul Tsani 1437 H.

Pondok Pesantren Mambaus Sholibin 5 Kedungsumber Balongpanggang Gresik. Gresik: majalah al-Fikrah edisi 88 Januari 2016 M/Rabiul Tsani 1437 $\mathrm{H}$.

Purwanto, M. Ngalim. Ilmu Pendidikan: Teoretis dan Praktis. Bandung: Remaja Rosdakarya, 2011.

Rettob, Theresia. "Motivasi dalam Proses Pemerolehan Bahasa Kedua" dalam Nurhadi dan Roekhan Dimensi-dimensi dalam Belajar Babasa Kedua. Bandung: Sinar Baru Bandung dan YA3 Malang, 1990. 
Șalâh Abd al-Majîd al-Arabî, Ta'allum al-Lughah al-Hayyah wa Ta'lîmuhâ. Kairo: Maktabah Lubnân, 1981.

Yayasan Pondok Pesantren Mambaus Sholihin, al-Sirah Majalab Tabunan. Gresik: Yayasan Pondok Pesantren Mambaus Sholihin, 2004.

Zuhdi, Halimi. "Lingkungan Bahasa Arab dan Perannya dalam Belajar Dan Pembelajaran di Pondok Pesantren al-Amien Prenduan Sumenep Madura”. Tesis--UIN Maulana Malik Ibrahim, 2007.

Zuhdi, Halimi. al-Bîah al-Lughawîyah Takwînuhâ wa Dawruhâ fî Iktisâb alArabiyah. Malang: UIN Malang Press, 2009. 